2. To: (Receiving Organization)

BWHC 300 Area Stabilization Project

5. Proj//Prog/Dept/Div.:

300 Area Stabilization Project

8. Originator Remarks:

This document is for public release.

11. Receiver Remarks: 11A. Design Baseline Document? [] Yes [X] No
3. From: (Originating Organization) 300 Area Baseline Planning and Control 6. Design Authority/ Design Agent/Cog. Engr.:

S. D. Landsman

Related EDT No:

N/A

7. Purchase Order No.:

N/A

9. Equip./Component No.

N/A

10. System/Bldg/Facility:

324 Building

12. Major Assm. Dwg. No.:

N/A

13. Permit/Permit Application No.:

N/A

14. Required Response Date:

May 26, 1998

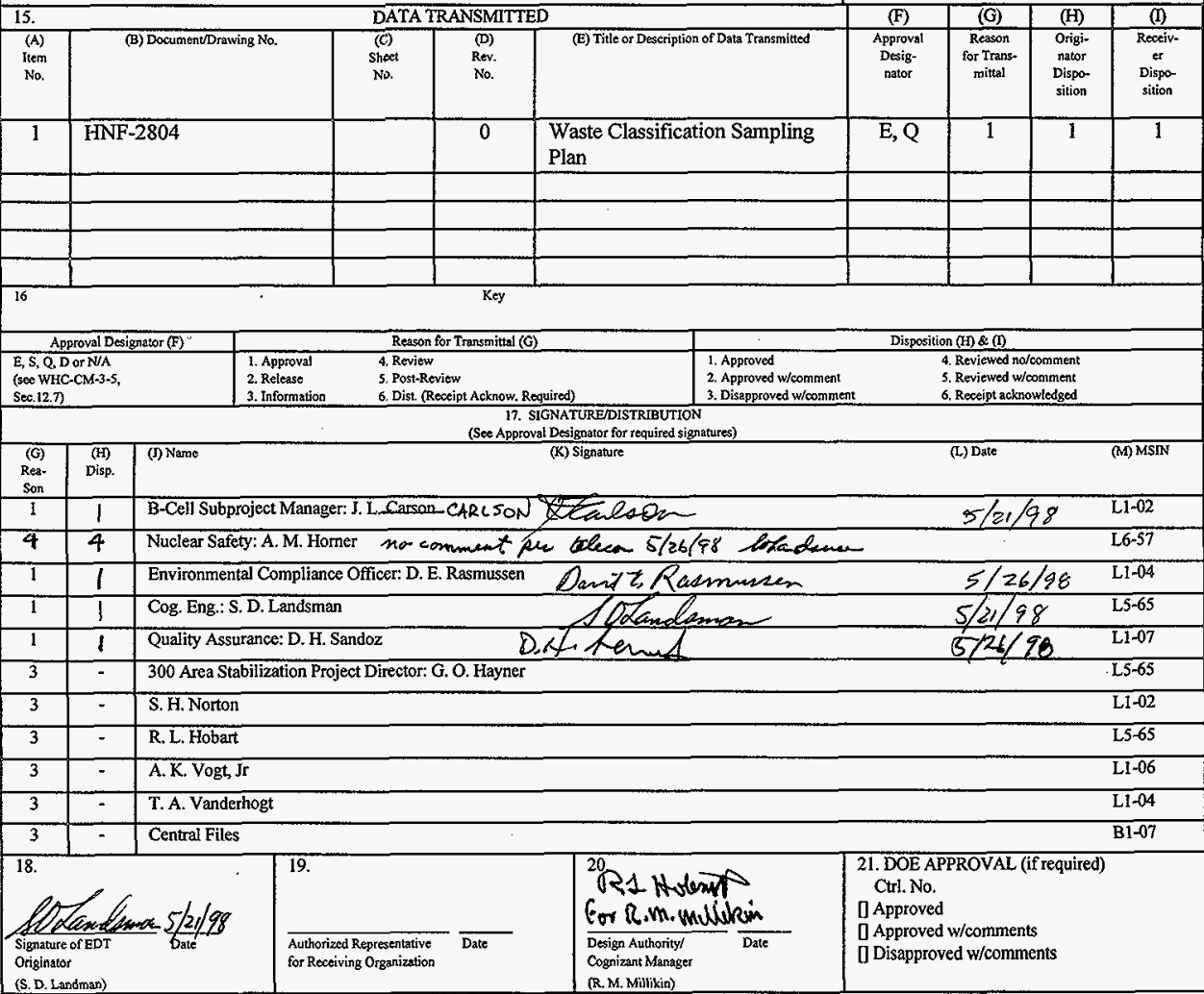




\title{
Waste Classification Sampling Plan
}

\author{
S.D. Landsman \\ B\&W Hanford Company, Richland, WA 99352 \\ Richland, WA 99352 \\ U.S. Department of Energy Contract DE-AC06-96RL13200
}

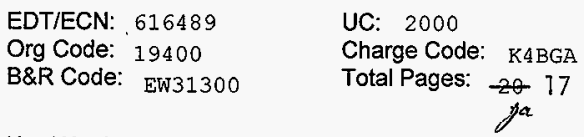

Key Words:

Low-level waste, transuranic, Alpha Energy Analysis, Decontamination Factor and Gamma Energy Analysis.

\begin{abstract}
:
The purpose of this sampling is to explain the method used to collect and analyze data necessary to verify and/or determine the radionuclide content of the B-Cell decontamination and decommissioning waste stream so that the correct waste classification for the waste stream can be made, and to collect samples for studies of decontamination methods hat could be used to remove fixed contamination present on the waste.
\end{abstract}

TRADEMARK DISCLAIMER. Reference herein to any specific commercial product, process, or service by trade name, trademark, manufacturer, or otherwise, does not necessarily constitute or imply ifs endorsement, recommendation, or favoring by the United States Government or any agency thereof or its contractors or subcontractors.

Printed in the United States of America. To obtain copies of this document, contact: Document Control Services, P.O. Box 950, Mailstop H6-08, Richland WA 99352, Phone (509) 372-2420; Fax (509) 376-4989.

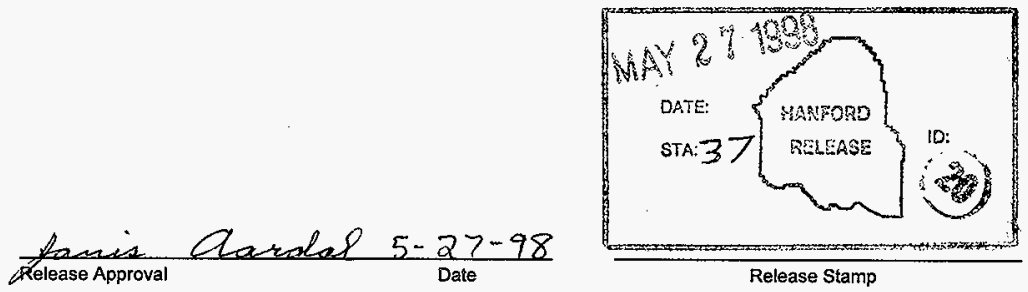

\section{Approved For Public Release}


HINF-2804, Rev. 0

\section{Waste Classification Sampling Plan}

HNF-2804, Rev. 0

May 1998

Prepared by:

B\&W Hanford Company, Richland, WA 99352

Prepared for:

U.S. Department of Energy, Richland Operations Office Richland, Washington 
HNF-2804, Rev. 0

This page intentionally left blank 


\section{Waste Classification Sampling Plan}

\section{TABLE OF CONTENTS}

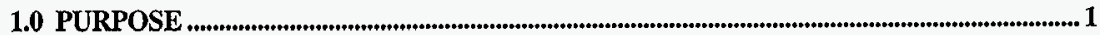

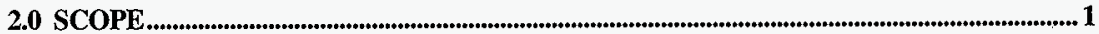

3.0 BACKGROUND .......................................................................................................................................... 1

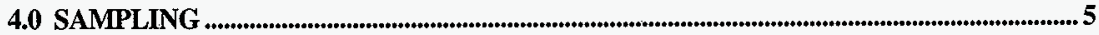

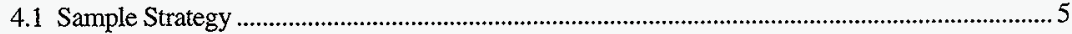

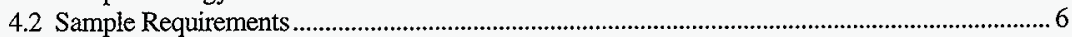

4.3 Sample Collection........................................................................................................................

5.0 ANALYTICAL PROCEDURES TO BE PERFORMED.................................................... 9

5.1 Waste Classification Specimens ..........................................................................................

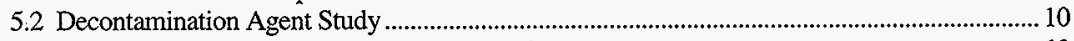

6.0 COUPON TESTS AND MEASUREMENTS: ....................................................................... 10

\section{FIGURES AND TABLES}

Figure 1. Methodology Used to Calculate Isotopic Content of B-Cell Waste Containers ...................... 3

Figure 2. Contributions of Contamination Types to Waste Container Dose Rates.................................... 4

Table 1. Decontamination Reagents to be Tested.................................................................................. 11

\section{TERMS}

$\begin{array}{ll}{ }^{137} \mathrm{Cs} & \text { Cesium-137 } \\ { }^{90} \mathrm{Sr} & \text { Strontium-90 } \\ \mathrm{AEA} & \text { Alpha Energy Analysis } \\ \mathrm{CI} & \text { confidence interval } \\ \mathrm{DF} & \text { Decontamination Factor } \\ \text { GEA } & \text { Gamma Energy Analysis } \\ \text { ID } & \text { identification. } \\ \text { JCS } & \text { job control system } \\ \text { LLW } & \text { low-level waste } \\ \text { TRU } & \text { transuranic }\end{array}$


HNF-2804, Rev. 0

This page intentionally left blank. 
HNF-2804, Rev. 0

\subsection{PURPOSE}

The purpose of this sampling plan is to explain the method used to collect and analyze data necessary to verify and/or determine the radionuclide content of the B-Cell decontamination and decommissioning waste stream so that the correct waste classification for the waste stream can be made, and to collect samples for studies of decontamination methods that could be used to remove fixed contamination present on the waste.

\section{$2.0 \mathrm{SCOPE}$}

The scope of this plan is to establish the technical basis for collecting samples and compiling quantitative data on the radioactive constituents present in waste generated during deactivation activities in B-Cell. Sampling and radioisotopic analysis will be performed on the fixed layers of contamination present on structural material and internal surfaces of process piping and tanks. In addition, dose rate measurements on existing waste material will be performed to determine the fraction of dose rate attributable to both removable and fixed contamination. Samples will also be collected to support studies of decontamination methods that are effective in removing the fixed contamination present on the waste.

Sampling performed under this plan will meet criteria established in HNF-2596, Data Quality Objectives for the B-Cell Waste Stream Classification Sampling, J. M. Barnett, May 1998.

\subsection{BACKGROUND}

It is the waste generators' responsibility to classify any waste stream that is generated and sent through the waste management process at Hanford. For waste streams generated over long periods of time, a periodic check of characterization data should be conducted to ensure that the waste stream is still within the classification boundaries.

A review of the B-cell Cleanout waste stream classification by B\&W Hanford Company determined that worst-case waste packages generated by the program may fall outside the boundary limits of the waste stream. The current method for designating $\mathrm{B}$-Cell waste is based on analytical characterization of residual removable contamination on rinsed surfaces of B-Cell. Process knowledge indicates that most of the contamination in B-Cell is fixed and that the isotopic distribution of radionuclides in the fixed layers is significantly different from that of the residual removable contamination. Additionally, process knowledge indicates that the fixed contamination is likely to contain less alpha contamination than the removable contamination. Demonstration of this indication would allow much of the waste in B-Cell to be designated as low-level waste (LLW).

In the past, process knowledge of the origin of radionuclide contamination present in the BCell waste stream was deemed sufficient to allow classification of metal waste being removed from the cell as low-level waste, as long as the removable contamination was rinsed off the waste. It was assumed that the fixed contamination present on material in the cell was a product of a melter off-gas release, and contained the same mixtures of isotopes (Strontium-90 $\left[{ }^{90} \mathrm{Sr}\right]$ and Cesium-137 $\left[{ }^{137} \mathrm{Cs}\right]$ ) that was present in the melter at the time of release. Similarly, it was assumed that rinses of process 
equipment performed after processing removed the majority of process solution residuals from piping and vessels. No documentation can be found that specifically verifies these conditions.

The methodology used to determine the nuclide content of waste packages and to designate the waste removed from B-Cell is shown schematically in Figure 1. Dose rate profiles of containers are performed after grouting. The average dose rate at the surface of the container is calculated from the dose rate profiles. The primary Gamma dose contributor in the waste stream is known through process history and analytical data to be ${ }^{137} \mathrm{Cs}$. Computer modeling is used to estimate the amount of ${ }^{137} \mathrm{Cs}$ necessary to generate the observed average dose rate of the container. This information is then used to estimate the amounts of other radionuclides present in the waste by multiplying the ${ }^{137} \mathrm{Cs}$ content by the ratio of alpha-emitting radionuclide activity to ${ }^{137} \mathrm{Cs}$ activity.

The alpha: ${ }^{137} \mathrm{Cs}$ ratio currently being applied to $\mathrm{B}$-Cell waste was determined through the analysis of six smears taken from rinsed surfaces in B-Cell. Analysis of the six smears has also indicated that only $80 \%$ of the alpha activity is emitted by transuranic (TRU) radionuclides; isotopes of Curium present in the waste are not classified as TRU because of their short half lives.

After the alpha activity is estimated using the above method, the alpha concentration of the waste is determined by dividing the alpha activity by the weight of the grouted waste. If the alpha concentration is below $100 \mathrm{nCi} / \mathrm{g}$, the waste is designated as LLW. If the alpha concentration is greater than $100 \mathrm{nCi} / \mathrm{g}$ but less than $125 \mathrm{nCi} / \mathrm{g}$, then the waste is designated as greater than Category C waste. If the alpha concentration of the waste is greater than $125 \mathrm{nCi} / \mathrm{g}$, then the waste is designated as TRU waste.

Dose rates observed on containers of waste originates from radioactive contamination present on the waste. The contamination present in the B-Cell waste stream originates from three distinct sources (Figure 2):

- Process residuals present inside piping and vessels involved in past engineering processes.

- Removable contamination present in the cell from process upsets and spills. This material is deposited on the waste during the course of normal cell operations, but the majority of this material is removed from the waste by a pressurized water rinse.

A fixed layer of material that is present on exposed metal surfaces in the cell. This fixed layer is known to exist because observed dose rates on containers of rinsed waste comprised only of structural materials from the racks (rack legs and structural support members that were not directly exposed to process solutions) range from $10 \mathrm{R} / \mathrm{hr}$ to $100 \mathrm{R} / \mathrm{hr}$. This fixed layer is thought to have originated from plating of volatilized materials released from the radioactive liquid-fed ceramic melter during production of the FRG glass logs. 
Figure 1. Methodology Used to Calculate Isotopic Content of B-Cell Waste Containers

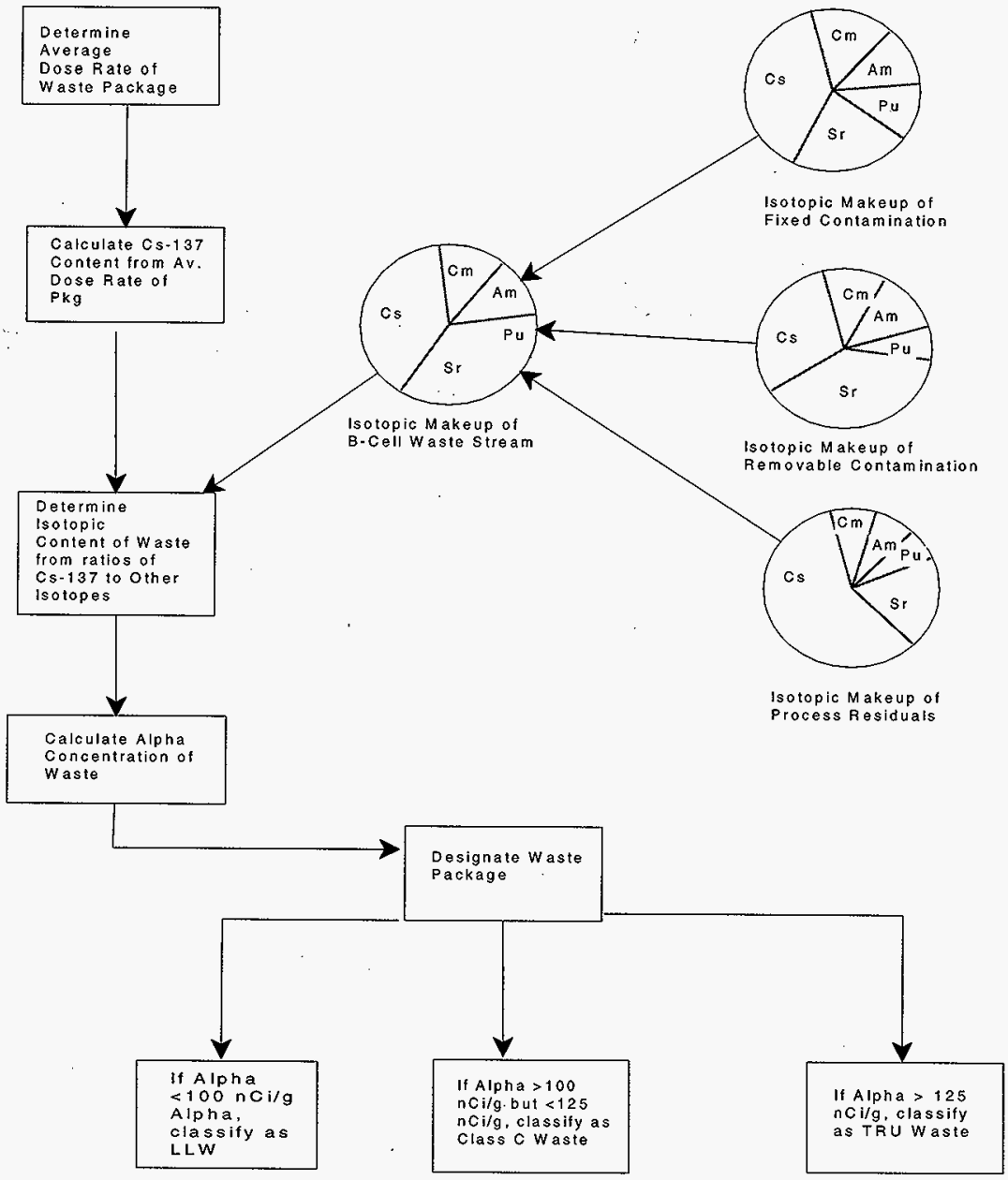


HNF-2804, Rev. 0

Figure 2. Contributions of Contamination Types to Waste Container Dose Rates

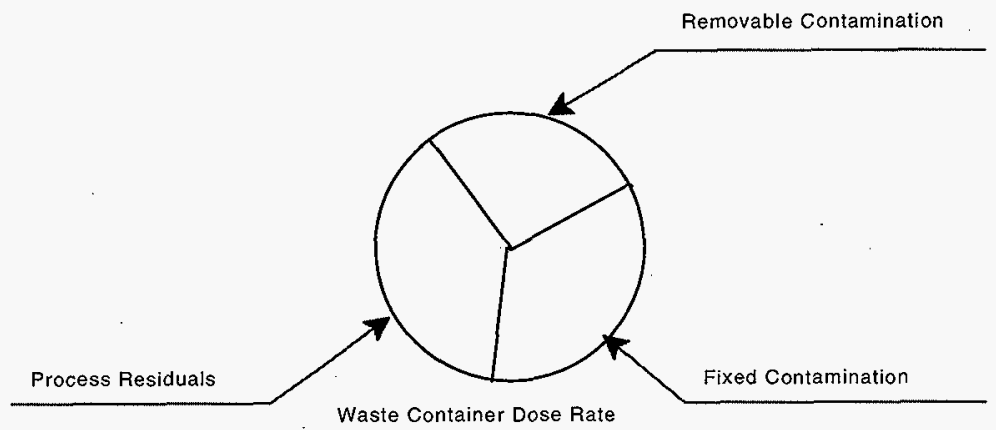


HNF-2804, Rev. 0

Although analytical information of radionuclides present in process solutions used as feedstock during vitrification projects is available, no isotopic characterization of process residuals present as fixed contamination inside piping and auxiliary vessels has been performed. Also, no isotopic characterization of fixed contamination present on extemal surfaces of the equipment racks has been obtained. Radioanalytical information from smears of removable contamination present in the cell is the only direct information available to perform the radionuclide scale up after dose rates are established for the waste containers generated.

- To correctly classify the B-Cell waste stream as LLW, Greater-than-Category C waste, or TRU waste, data on the radionuclide content of fixed contamination inside process lines or on external surfaces of structures in the waste stream must be collected. This information, along with radionuclide information for removable contamination, will be used to establish the relationship between ${ }^{137} \mathrm{Cs}$ and the Alpha emitting radionuclides present in the waste stream. This relationship will be used to determine the alpha content of individual waste packages generated from this waste stream.

\subsection{SAMPLING}

\subsection{Sample Strategy}

The source of the waste stream being examined is process equipment racks present in B-Cell. The racks consist of tanks and vessels, and process and utility piping that is contained inside a structural support. All of the rack components are metal. Process history was used to determine the populations present on the racks that may require sampling. The following assumptions, based on process history, were considered pertinent to establishing sample populations:

- All external surfaces present on the rack were coated with 'fixed' contamination during a 1985 melter off-gas release to the cell.

- $\quad$ Process piping and auxiliary vessels such as de-misters, condensers, off-gas heaters, and condensate collection tanks in the racks were rinsed during and after process work were completed. This means that they are relatively clean and contain no residual process sludge. It is anticipated, however, that a layer of fixed contamination will be present inside the process piping and auxiliary vessels.

- Utility piping in the racks was not internally exposed to process solutions or effluent, as indicated by process history.

- Primary tanks in the equipment racks contain large amounts of process sludge that cannot be readily removed from the tanks and are likely to contain hazardous constituents, making them mixed waste. This condition will require handling the primary tanks as Special Case Waste, so they can be excluded from this waste stream. For more information on disposition of primary tanks, see HNF-1730, Rev. 1, 324/327 Buildings Special Case Waste Assessment and Disposition Alternatives Analysis, March 1998. 
HNF-2804, Rev. 0

Based on these assumptions, the following sample populations were identified:

- Ungrouted waste in grout containers (although this material came primarily from demolished equipment racks, other material such as Tank 119 have been cut up and are present in the grout containers).

- External surfaces of piping and tubing, tanks, and rack structural material on intact racks.

- Internal surfaces of structural material on intact racks.

- Internal surfaces of piping and tubing on intact racks.

- Internal surfaces of tanks 'and vessels in intact racks.

Of the five populations, it is expected that population " $c$ " will not have significant quantities of fixed contamination because the internal surfaces were not directly exposed to either process solutions or volatile airborne fractions from the melter. The remaining internal surfaces represented by populations " $\mathrm{d}$ " and " $\mathrm{e}$ " are expected to have fixed contamination with similar radioisotopic characteristics because components in these two populations were exposed to the same process solutions, and were concurrently rinsed in the same manner. For the purposes of this plan, therefore, populations " $\mathrm{d}$ " and "e" will be grouped into one population known as 'internal surfaces'. Samples will be collected from both populations, however.

Population " $a$ " is not expected to exhibit different radionuclide characteristics than the intact racks, since the origin of material in the grout containers is demolished racks and other equipment that was subjected to conditions identical to those experienced by the intact racks. Material from this population, however, will be used to determine the contributions of removable and fixed contamination to the total dose rate seen on individual containers in the cell.

In summary, the following populations will be sampled:

- Ungrouted waste in grout containers (samples will determine the contribution of removable contamination to total dose rate).

- External surfaces of the racks, including structural materials, exterior surfaces of tanks, vessels and piping.

- Internal surfaces of equipment in the racks, including process piping and auxiliary tanks and vessels.

\subsection{Sample Requirements}

The technical basis for obtaining samples for analysis in B-Cell is contained in the document A Technical Basis for a Statistical Sampling Plan for Rack, Process Piping, and Tanks in B-Cell 
(Jenson and Wilmarth, 1998). This section summarizes the requirements described in the technical basis document.

The sampling plan should be applied to each population using three steps. The three steps are: (1) select multiple locations within each population, (2) obtain duplicate samples or smears from each location and (3) measure the activity on each sample or smear. The sample locations within each population should be chosen at random. Randomization is the guarantee that the results, based on the samples, can be applied to the population.

While obtaining samples, extraneous sources of variability will be minimized by keeping the sample area constant and by using the same equipment, techniques, and personnel for obtaining all samples. This will minimize variability in the data caused by sampling activities. Variability in analysis activities will be minimized by obtaining duplicate samples from each location.

The uncertainty in the mean activity of ${ }^{137} \mathrm{Cs},{ }^{90} \mathrm{Sr}$, and alpha-emitting radionuclides is determined based on the upper limit of a one-sided $95 \%$ confidence interval (CD) on the mean. In order for the upper limit on the mean to be 1.5 times the mean (for measurements of ${ }^{137} \mathrm{Cs}$ activity), a total of 15 samples must be obtained for each population. Twenty measurements are required to obtain the same CI for alpha activity. Sub-populations within the population will have larger values of the upper limit. For example, if six samples are taken from process tanks (a sub-population of the internal surfaces population) then the CI for that sub-population is two times the mean for that subpopulation. Thus, it is possible to design a sampling plan that provides a CI of 1.5 times the mean for a population and that provides information on the variability between sub-populations within that population.

It is often appropriate for a sampling experiment to consist of several phases. In the first phase, a set of duplicate results from randomly selected locations within each population is obtained. Based on the data, the width of the one-sided $95 \%$ confidence interval on the mean activity of ${ }^{137} \mathrm{Cs}$, ${ }^{90} \mathrm{Sr}$, and alpha is computed and compared to a criteria. If the variability in the data (relative to the criteria) is small then the experiment may not require a second iteration. If the variability is large, a second step would be to estimate the number of additional sample locations required to satisfy the criteria and to obtain the additional observations.

The number of locations in the first stage of the experiment needs to be large enough so that sample results are available from the external surface area, the internal area of process piping, and the internal area of tanks for each of the three racks, 1A, 2A, and 1B. To meet the acceptable error limits specified in the Data Quality Objectives, it was determined that samples from 15 locations would be collected for each sample population.

Locations that can be sampled are restricted due to the limited movement of the in-cell manipulators. Rack IA can be repositioned to allow samples to be taken virtually anywhere on the rack, however, sample locations on the $1 \mathrm{~B}$ and $2 \mathrm{~A}$ Racks are limited to the faces of the rack. Subsequently, more samples will be collected from the 1A Rack, but corresponding samples will be taken from the $1 \mathrm{~B}$ and $2 \mathrm{~A}$ Racks when possible. 
For the internal contamination population, nine samples will be collected from process piping, and six samples will be collected from auxiliary tanks and vessels in the racks. Process piping samples will be collected from the rack faces, so it will be possible to collect three samples from each rack. It will not be possible to collect samples from auxiliary tanks and vessels located in the 2A Rack due to inaccessibility. Three samples per rack will be collected from auxiliary tanks and vessels in the $1 \mathrm{~A}$ and $1 \mathrm{~B}$ Racks.

It will be possible to group the samples according to different location characteristics the samples share. This will allow calculation of several Confidence Intervals using the same data, which will serve to determine how adequate the initial sample phase is. For instance, all 15 samples can be analyzed to determine the $\mathrm{Cl}$ for internal surfaces. The nine samples of piping can be analyzed together to determine the CI for piping, and the six samples from auxiliary tanks and vessels can be analyzed to determine the $\mathrm{CI}$ for that sub-population. Other combinations are also possible, such as grouping samples from each rack.

A similar methodology can be used for samples collected from the external contamination population. Fifteen samples will be collected from the three intact racks. Since the 1A Rack is positioned in the middle of the cell and can be moved, two samples will be taken on the top, middle, and bottom of the front face of the rack. The rack will then be rotated to allow a sample to be taken from each side of the rack, and one sample at the top, middle, and bottom of the back face of the rack. Two samples will also be collected from the middle of the front face of both the 1B and 2A Racks in the same locations that correspond to samples collected from the middle front face of the 1A Rack. Sample results will be grouped together in different combinations determined by similar characteristics the samples share, and analyzed for the resulting CI. This will determine how adequate the initial sample phase is.

\subsection{Sample Collection}

Samples will be collected under this sample plan for several different purposes.

Samples will be collected from sample population "a", the ungrouted waste from sample containers already in-cell, to establish the contribution of removable contamination to the total dose rate seen on individual containers in the cell.

A total of 10 samples will be randomly selected from metal waste present in ungrouted waste containers in the cell. The samples will be transported to the Radiochemical Engineering Cells Airlock, where the samples will be uniquely identified. Initial dose rates will be taken using a remote detector, then the samples will be coated with a strippable coating that will remove the removable contamination present on the sample. Dose rates will be obtained from both the sample piece and the strippable coating after the strippable coating has been removed. This will allow a separate determination of how much dose rate is contributed by removable contamination present on the waste, and by the fixed contamination present on the waste. Dose rates and other pertinent information such as sample identification (ID) number and dose rate instrument calibration information will be collected on a data sheet that will be included in the job control system (JCS) package generated to support this work. 
Metal specimens will be collected 'In Situ' as described above from intact racks in the cell to determine the radioisotopic characteristics of fixed contamination.

Thirty metal specimens will be collected from the racks using 1-1/4 inch hole saws. The hole saws will be uniquely numbered prior to going into the cell. The metal specimens will be collected in batches, depending on which rack is being sampled. Once a specimen is collected, it will remain in the hole saw until it is received at the laboratory, so that the surface of interest (internal or external) can be easily determined by laboratory personnel. This will also ensure correct identification of the sample by the laboratory.

Exact sample locations, $\mathrm{D}$ numbers for each sample, and pertinent remarks will be recorded on a data sheet that will be included in the JCS package generated to control this work. A copy of the data sheet will accompany the samples when the samples are sent to the laboratory. This will ensure that sample ID information is supplied to the laboratory.

Additional metal specimens will be collected to perform chemistry studies to characterize the chemical makeup of the fixed contamination, so that appropriate decontamination methods for metal surfaces in the cell can be determined.

A total of nine specimens will be collected using 1-1/4 inch hole saws from locations at the top, middle, and bottom of the front face of the 1A Rack. Exact sample locations, ID numbers for each sample, and pertinent remarks will be recorded on a data sheet that will be included in the JCS package generated to control this work. A copy of the data sheet will accompany the samples when the samples are sent to the laboratory. This will ensure that sample $\mathrm{ID}$ information is supplied to the laboratory.

\subsection{ANALYTICAL PROCEDURES TO BE PERFORMED}

\subsection{Waste Classification Specimens}

The 30 metal specimens slated for radioisotopic analysis will be sent to the laboratory in the hole saws used to collect the specimens. Following sample identification and analytical request information supplied by the customer, laboratory personnel will remove the metal specimen from the hole saw, maintaining specimen orientation. Depending on which surface is specified to be analyzed, the opposite side will be masked with paraffin, tape, or other masking agent, or protected in some manner that ensures that only material of interest is removed. Each specimen will then be cut in half so that two samples are produced. Acid dissolution of the surface of interest will then be performed on each sample. Aliquots of the resulting solute will be used to perform the following analyses for all 60 samples:

- Gamma Energy Analysis (GEA) per approved Laboratory protocols

- Alpha Energy Analysis (AEA) per approved Laboratory protocols

- ${ }^{90} \mathrm{Sr}$ analysis per approved Laboratory protocols. 
HNF-2804, Rev. 0

\subsection{Decontamination Agent Study}

A total of nine specimens will be provided to perform the following decontamination development tests.

The following discussion outlines a development program to test various decontamination reagents on metal surface specimens cut from racks in B-Cell 324 Facility. A base case test is outlined below. In addition, it is expected that Scanning Electron Microscope and Electron Dispersion Scanning data will also be gathered from at least one specimen. For all tests, the cognizant engineer will collaborate with the laboratory personnel performing the work, and will direct any changes to the procedures to be followed. It is probable that additional tests will be performed based on the interim results.

Tests will be conducted in a radiochemistry lab to demonstrate the response of the tightly adherent film to various chemistry conditions. Analysis will be done on the resultant solutions and coupons to measure the kinetics of dissolution and the completeness of dissolution. Part or all of a coupon may be used for each test. A total of nine coupons cut with a 1-1/4 inch hole saw will be supplied for the tests. The size of each test specimen subjected to a test will be primarily determined by the coupon dose rate.

The active film area of any coupon on portion of coupon should be measured using the best available methods. When coupons are subdivided it is also suggested that other estimates be made of the specimen by weight and by gamma spectroscopy if possible. This is necessary to define as well as possible, the radioactive film area being subjected to chemistry. All data are eventually referenced to the $\mathrm{cm}^{2}$ area of radioactive film.

Each initial coupon should be given an ID number, if not already assigned and any parts of it the same identification. The rack sample locations should be available with the original specimens.

\subsection{COUPON TESTS AND MEASUREMENTS:}

\section{Baseline Measurement}

From one specimen, physically remove a portion of the fixed contamination film with scraper and analyze leach solution for (1) metals and (2) anions

\section{$\underline{\text { Reagent Testing }}$}

Pretreat a specimen by soaking in 50 centigrade DI water for 20 minutes. Suspend the specimen in stirred reagent at specified temperature for the specified residence time (see table below). Dose rates of the specimen will be collected every 15 minutes for first hour, every 30 minutes for second hour, and every 60 minutes for the remaining time. 
After reagent contact time is done, coupon will be rinsed and the final dose rate of the specimen taken. Compare the initial dose rate of the specimen to the final dose rate. If the Decontamination Factor (DF) is less than 5, store the specimen. If the DF is greater than 5, scrape a portion of the residual film left on the specimen, and prepare the scrapings for analysis by dissolving in mixed acids.

Analyses will need to be performed on the following solutions for each decontamination agent tried:

- Pretreat water

- Reagent solution

- Film strip solution

For each solution, perform the following analyses:

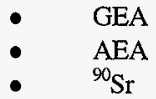

Table 1. Decontamination Reagents to be Tested

\begin{tabular}{|c|c|c|c|c|}
\hline REAGENT & Test No. & $\begin{array}{c}\text { Test } \\
\text { Temp }{ }^{\circ} \mathrm{C}\end{array}$ & $\begin{array}{c}\text { Test Time } \\
\text { (Hours) }\end{array}$ & NOTES \\
\hline NITRIC & 1 & 70 & 4 & \\
\hline CITRIC & 2 & 70 & 4 & \\
\hline $\mathrm{NaOH}$ & 3 & 70 & 4 & \\
\hline AP & 4 & 70 & 2 & $\begin{array}{l}\text { TWO STAGE TREATMENT WATER } \\
\text { FLUSH BETWEEN }\end{array}$ \\
\hline CITROX & 4 & 70 & 6 & SECOND STAGE OF SEQUENCE \\
\hline $\mathrm{AP}$ & 5 & 70 & 2 & $\begin{array}{l}\text { TWO STAGE TREATMENT WATER } \\
\text { FLUSH BETWEEN }\end{array}$ \\
\hline NITRIC & 5 & 70 & 4 & SECOND STAGE OF SEQUENCE \\
\hline $\mathrm{Ce}+4 / \mathrm{NITRIC}$ & 6 & 70 & 2 & \\
\hline $\mathrm{AP}$ & 7 & 70 & 2 & $\begin{array}{l}\text { TWO STAGE TREATMENTWATER } \\
\text { FLUSH BETWEEN }\end{array}$ \\
\hline FORMIC ACID & 7 & 50 & 4 & SECOND STAGE \\
\hline FORMIC ACID & 8 & 70 & 6 & SINGLE STAGE CONTACT \\
\hline FORMIC ACID & 9 & 70 & 6 & SINGLE STAGE CONTACT \\
\hline $\begin{array}{l}\text { DuBoise alkali } \\
\text { Foam }\end{array}$ & 10 & N/A & 1 & $\begin{array}{l}\text { Wash with DI measure dose } \\
\text { Save wash for analysis }\end{array}$ \\
\hline Repeat foam & 10 & & & \\
\hline Repeat foam & 10 & & & \\
\hline Repeat foam & 10 & & & \\
\hline
\end{tabular}

$\mathrm{AP}=2.5 \mathrm{M} \mathrm{NaOH}$

$0.2 \mathrm{M} \mathrm{KmnO} 4$
** CITROX $=0.3 \mathrm{M}$ Oxalic

$0.2 \mathrm{M}$ Citric 
HNF-2804, Rev. 0

This page intentionally left blank. 